\title{
Competências Leitoras no Saeb: qualidade da leitura na educação básica
}

\author{
Janete Bridon' \\ Adair de Aguiar Neitzel' \\ 'Universidade do Vale do Itajaí (UNIVALI), Itajaí/SC - Brasil
}

RESUMO - Competências Leitoras no Saeb: qualidade da leitura na educação básica. Este artigo discute como as políticas de avaliação, em especial o Saeb, podem colaborar para a qualidade da educação básica. Ele identifica as competências em leitura indicadas pelo Saeb e analisa como os alunos encontram-se em relação à leitura. Esta é uma pesquisa qualitativa e exploratória, sendo os instrumentos de coleta de dados: o Plano de Desenvolvimento da Educação: Prova Brasil; os documentos que tratam dos níveis de escala e desempenho em língua Portuguesa do Inep (2011); e os resultados do SAEB/Prova Brasil 2011 (Brasil, 2012). Como resultado, apresentamos que, para alcançar os níveis mais altos de compreensão leitora, os alunos necessitam desprender-se do texto fácil e adentrar sistematicamente no universo da leitura.

Palavras-chave: Políticas Públicas. Avaliação. Leitura. Aneb.

ABSTRACT - Reading Competencies in Saeb: reading quality in basic education. This article discusses how assessment policies, particularly Saeb, can contribute to the quality of basic education. It identifies the reading skills indicated by Saeb and analyzes how the students are with regard to reading. This is a qualitative and exploratory research, being the instruments for data collection: the Development Plan for Education: Prova Brasil; documents which deal with the scale and performance levels in Portuguese of Inep (2011), and the results of Saeb/Prova Brasil 2011 (Brasil, 2012). As a result, it is presented that in order to students achieve higher levels of reading comprehension, they need to detach themselves of the easy text and enter sistematically in the world of reading.

Keywords: Public Policies. Evaluation. Reading. Aneb.

Educação \& Realidade, Porto Alegre, v. 39, n. 2, p. 437-462, abr./jun. 2014.

Disponível em: <http://www.ufrgs.br/edu_realidade> 


\section{Introdução}

Como promover a melhoria da qualidade da educação básica? Segundo Libâneo (2008, p. 168), esta depende da aproximação entre "as políticas educacionais, a legislação educacional, a pesquisa acadêmica, e o que o acontece na realidade das escolas". O Brasil vem, ao longo dos últimos vinte anos, intensificando o número de políticas públicas voltadas à educação que alteram, de alguma forma, a rotina escolar - políticas como a do Plano Nacional do Livro Didático, o Plano Nacional da Educação, as Avaliações do Saeb e, recentemente, o Programa Institucional de Bolsas de Iniciação à Docência. Quando uma política pública é instituída, várias são as metas também traçadas. Por exemplo, o novo Plano Nacional da Educação 2011-2020 (PNE), ainda a ser aprovado pelo Congresso Nacional, estabelece em sua meta 7: "Atingir as seguintes médias nacionais para o IDEB":

Tabela 1 - Médias nacionais do Índice Nacional de Desenvolvimento da Educação Básica (IDEB) a serem atingidas

\begin{tabular}{ccccccc}
\hline IDEB & $\mathbf{2 0 1 1}$ & $\mathbf{2 0 1 3}$ & $\mathbf{2 0 1 5}$ & $\mathbf{2 0 1 7}$ & $\mathbf{2 0 1 9}$ & $\mathbf{2 0 2 1}$ \\
\hline Anos iniciais do ensino fundamental & 4,6 & 4,9 & 5,2 & 5,5 & 5,7 & 6,0 \\
Anos finais do ensino fundamental & 3,9 & 4,4 & 4,7 & 5,0 & 5,2 & 5,5 \\
Ensino médio & 3,7 & 3,9 & 4,3 & 4,7 & 5,0 & 5,2 \\
\hline
\end{tabular}

Fonte: Adaptada pelas autoras de Brasil (2010, p. 8).

A elevação das médias nacionais depende da articulação entre as macropolíticas e as micropolíticas. Aumentar os índices do IDEB compreende ações que, de forma direta, promovam um movimento na cultura escolar, que deve ser provocado pelas políticas públicas, mas que precisa ter o envolvimento dos sujeitos que atuam diretamente no processo educativo, pois é na escola que essas políticas são implementadas. Libâneo (2008, p. 177), com relação a essa questão, acredita que “[...] a análise externa das questões educacionais é sumamente importante, elas nos põem alertas para uma visão política e contextualizada das coisas". E o pesquisador insiste: “[...] o processo educativo, o processo de ensino é endógeno, ele acontece de dentro para fora” (Libâneo, 2008, p. 177).

Tendo em vista que os resultados das avaliações do Saeb oferecem indicadores relevantes para ampliarmos a qualidade na educação básica, e que esses resultados só provocarão desacomodações quando discutidos e analisados pelos sujeitos envolvidos no processo educativo, trazemos à baila os resultados do Saeb no que diz respeito ao desempenho de leitura dos estudantes. As políticas de avaliação nacionais têm mostrado o baixo nível de adequação à aprendizagem dos alunos em compreensão leitora da escola básica no Brasil. Conforme os resultados da avaliação do Saeb (Brasil, 2012), muitos alunos do ensino fundamental, $45,95 \%$ do $5^{\circ}$ ano e $73,04 \%$ do $9^{\circ}$, encontram-se abaixo do nível 
considerado ideal, acarretando dificuldades de aprendizagem que são ampliadas de uma série para a outra. Se os problemas de compreensão leitora apresentados pelos alunos do $5^{\circ}$ ano não forem resolvidos durante sua caminhada, por exemplo, e novas competências não forem adquiridas, as problemáticas refletirão nos anos escolares posteriores.

Os resultados das avaliações do Saeb (Brasil, 2012) mostram que a maioria dos alunos brasileiros avaliados é capaz de lidar com informações explícitas ou, ainda, implícitas em um texto; podem fazer conexões nos limites do texto ou com seu conhecimento de mundo; têm a competência de reconhecer a finalidade de um texto e seu tema; podem estabelecer relações entre os elementos do texto. Entretanto, muitos desses jovens são capazes de usar tais competências apenas em textos simples.

Com o intuito de identificar as competências em leitura que o Saeb indica como necessárias à formação do leitor da educação básica e o que os alunos brasileiros são capazes de fazer nessas provas, investigamos o Plano de Desenvolvimento da Educação: Prova Brasil, o qual trata das matrizes de referência de Língua Portuguesa (Brasil, 2008); os documentos que abordam os níveis de escala e desempenho em língua Portuguesa do Instituto de Pesquisa Anísio Teixeira (Inep, 2011a; 2011b; 2011c; 2011d; 2011e); e os resultados do SAEB/Prova Brasil 2011 divulgados por Brasil (2012). Os dados coletados foram analisados e referendados teoricamente com o intuito de estabelecer relações entre as competências leitoras dos exames do Saeb e os níveis de compreensão leitora apontados por Gagné, Yekovich e Yekovich (1993). Os resultados irão sinalizar a urgência de se implementar ações pontuais nas escolas para ampliar as competências leitoras dos estudantes, um movimento que precisa partir dos agentes que fazem parte da rotina escolar, e que implicarão, diretamente, na qualidade da educação básica, uma vez que o domínio de competências leitoras é fundamental para o acesso a várias áreas do conhecimento. De acordo com o Plano de Desenvolvimento da Educação: Prova Brasil, “[...] a leitura é fundamental para o desenvolvimento de outras áreas do conhecimento e para o consequente exercício da cidadania" (Brasil, 2008, p. 21).

\section{O Leitor em Formação: a leitura e os níveis de compreensão leitora}

A leitura, para Gagné, Yekovich e Yekovich (1993, p. 135), permite que o mundo passe a fazer parte até da vida de indivíduos que vivem em localidades remotas. Ela possibilita que indivíduos cresçam profissionalmente e que façam descobertas relacionadas aos vários elementos que compõem não só seu entorno, mas também os de outras sociedades e culturas. Segundo os autores, há quatro níveis de compreensão leitora. Os dois primeiros, chamados de shallow processing, englobam a decodificação e a compreensão literal, níveis em que o leitor é capaz de perceber o texto de uma forma superficial. Já os dois últimos níveis

Educação \& Realidade, Porto Alegre, v. 39, n. 2, p. 437-462, abr./jun. 2014.

Disponível em: <http://www.ufrgs.br/edu_realidade> 
de compreensão leitora: inferência e monitoramento, o leitor tem a capacidade de embrenhar-se nos emaranhados do texto, de formar novos conceitos, de posicionar-se perante o texto. Tal nível de processamento é chamado de deep processing-níveis necessários e importantes na formação do leitor, pois é a partir daí que ele lidará com conceitos velhos e novos, fará relações e criará hipóteses. Assim sendo, os níveis de compreensão leitora de Gagné, Yekovich e Yekovich (1993) apresentam-se conforme a figura 1 que segue.

Figura 1 - Níveis de Compreensão Leitora

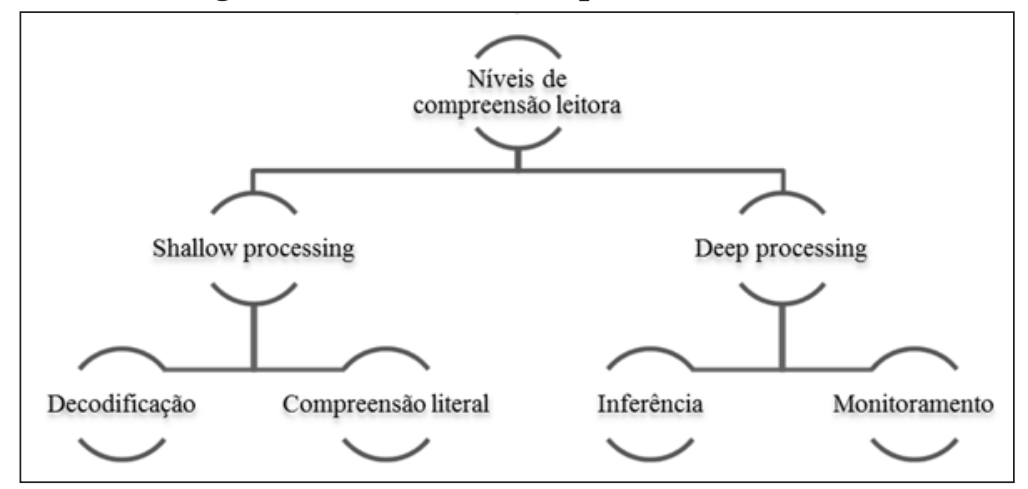

Fonte: Elaborada pelas autoras baseadas em Gagné, Yekovich e Yekovich (1993).

A convivência do aluno com a leitura no contexto escolar deve dar-se de forma a possibilitar que este atinja todos os níveis de compreensão leitora, para que o aluno leitor vá muito além de perceber o texto na sua superficialidade. Faz-se necessário, assim, pensar no que deve ler o leitor em formação, pois este precisa ser levado a compreender um texto em sua totalidade, para que ele seja capaz de criar hipóteses e entender textos longos e complexos com conteúdos não familiares - habilidades necessárias para se chegar aos níveis mais profundos de compreensão leitora.

Para isso, ele precisa, primeiramente, ser apresentado a textos que o levem a atingir esses níveis de compreensão. Quando apenas textos literários (ou não literários) que necessitam ser decodificados e compreendidos literalmente fazem parte do universo leitor do aluno, há grandes dificuldades de esse discente tornar-se um leitor que vá além da decodificação. O professor, assim, precisa provocar o leitor em formação, convidando o aluno a leituras que não esgotam seu sentido. Cabe ao docente propor questionamentos, chamar o aluno para a leitura ativa, abrir caminhos para que seu aluno torne-se um fruidor, um leitor que renove uma obra literária, por exemplo, a partir das reações que esta possa provocar-lhe.

Há, entretanto, uma pedra no sapato da fruição e dos níveis mais altos de compreensão leitora. Em muitos casos, mesmo que o aluno seja 
introduzido a textos abertos, os quais oferecem uma pluralidade de sentidos, se o docente não for um fruidor, aquele que também busca o que está escondido no emaranhado do texto, este acaba sendo tratado em sua superfície, ou seja, ele será apenas decodificado e compreendido literalmente, tanto pelo docente quanto pelos alunos, afinal tudo vai depender de como o texto será abordado e por que caminhos. Se adentrar-se o texto explicitamente, os discentes que ainda estão aprendendo a lidar com um texto, pois são leitores em formação, só perceberão as informações expostas claramente pelo autor em sua narrativa. Agora, se tomarem-se as vias do implícito, esses aprendizes poderão notar elementos que passariam despercebidos se ninguém lhes mostrasse as diversas possibilidades de leitura. Umberto Eco (2010), em seu livro Os limites da interpretação, traz um exemplo de como se pode tratar inadequadamente uma obra literária: ler Édipo Rei, de Sófocles, “[...] como um romance policial, em que a única coisa interessante se resumisse em encontrar o culpado" (Eco, 2010, p. 9). Contudo, "tomar as vias do implícito” requer um exercício que não seja episódico, visto que a passagem do explícito para o implícito necessita de quantidade e qualidade.

Para que o discente torne-se um leitor que atinja os níveis mais altos de compreensão leitora, ele precisa ser um fruidor. Mas, antes disso, seu professor necessita ser um fruidor, já que, na maioria das vezes, é a escola o local onde o discente é introduzido ao mundo da leitura. Portanto, o docente precisa emaranhar-se no mundo da literatura em busca do inusitado - todos ganham: docentes e discentes. Libâneo (2006), em seu artigo Sistema de ensino, escola, sala de aula: onde se produz a qualidade das aprendizagens?, discute sobre a distância entre o discurso da qualidade do ensino e da realidade da escola. É nela que as coisas acontecem, que mudanças ocorrem, que se percebe que o aluno aprendeu ou não a ler e a escrever.

\section{Avaliações Nacionais: Anresc e Aneb}

A Avaliação Nacional do Rendimento Escolar (ANRESC), mais conhecida como Prova Brasil, aplicada pela primeira vez em 2005, é a avaliação da qualidade proporcionada pelas escolas, recebendo o Brasil, cada região, cada estado, cada município e cada unidade escolar seu resultado global, procurando, assim, estimular tanto a qualidade quanto a equidade da educação básica, de forma a reduzir as desigualdades e cooperar com a democratização da gestão do ensino público (Brasil, 2005). A Prova Brasil, segundo o PDE/Prova Brasil (Brasil, 2008), é capaz de verificar se todos os alunos matriculados na escola básica valem-se de seu direito "[...] ao aprendizado de competências cognitivas básicas e gerais” (Brasil, 2008, p. 11). A Prova Brasil é aplicada a cada dois anos, acontecendo, a última, em 2011. A metodologia utilizada pela Anresc pode ser observada na figura 2 a seguir.

Educação \& Realidade, Porto Alegre, v. 39, n. 2, p. 437-462, abr./jun. 2014.

Disponível em: <http://www.ufrgs.br/edu_realidade> 
Figura 2 - Metodologia da Anresc

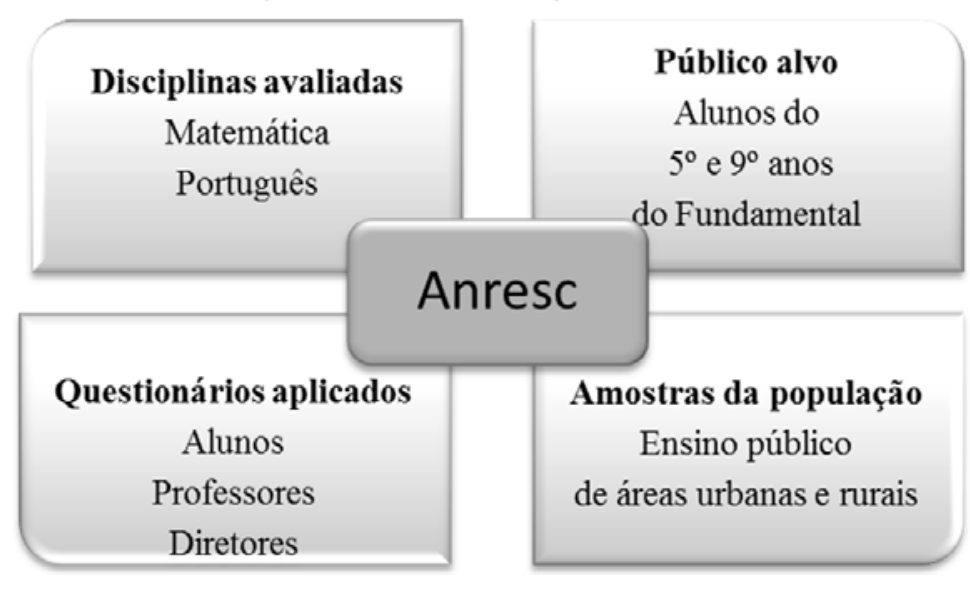

Fonte: Elaborada pelas autoras com base em Inep (2011a).

Na Prova Brasil, observam-se as competências em leitura (Língua Portuguesa) e a resolução de problemas (Matemática). Assim sendo, o nível de desempenho em relação à competência leitora e à resolução de problemas pode mostrar a quantas andam a aprendizagem dos discentes em todas as disciplinas do currículo escolar, já que em Ciências, em História, em Geografia, etc., há a necessidade de competência leitora e de resolução de problemas. Sem essa habilidade, o direito do discente “[...] ao aprendizado de competências cognitivas básicas e gerais" (Brasil, 2008, p. 11), como já apontado aqui, fica ameaçado.

A Anresc faz uso, também, de questionários respondidos por alunos, por professores e por diretores com o intuito de conhecer, de acordo com o Inep (2011b), “[...] as condições internas e externas que interferem no processo de ensino e aprendizagem". O sistema de avaliação coleta, também, dados sobre as condições físicas e os recursos da escola.

Em se tratando da Aneb, esta é uma avaliação feita por meio de amostras da população de larga escala do ensino público e do particular, de escolas das áreas urbanas e rurais. Dessa forma, devido ao seu caráter amostral, os resultados incidem apenas para o Brasil, para as regiões e para os estados. A avaliação é realizada bianualmente, cuja coleta e sistematização de dados são feitas por intermédio de procedimentos metodológicos formais e científicos a procura de "[...] produzir informações sobre o desempenho dos alunos do Ensino Fundamental e Médio, assim como sobre as condições intra e extra-escolares que incidem sobre o processo de ensino e aprendizagem" (Brasil, 2005). A intenção, de acordo com a Portaria no 931 (Brasil, 2005), é contribuir para a formulação de políticas públicas voltadas à educação que proporcionem melhoras na qualidade da educação nacional. Os objetivos são, portanto: avaliar a qualidade, a equidade e a eficiência da educação 
brasileira (Brasil, 2005). A metodologia utilizada pela Aneb pode ser observada na figura 3 a seguir.

Figura 3 - Metodologia usada pela Aneb

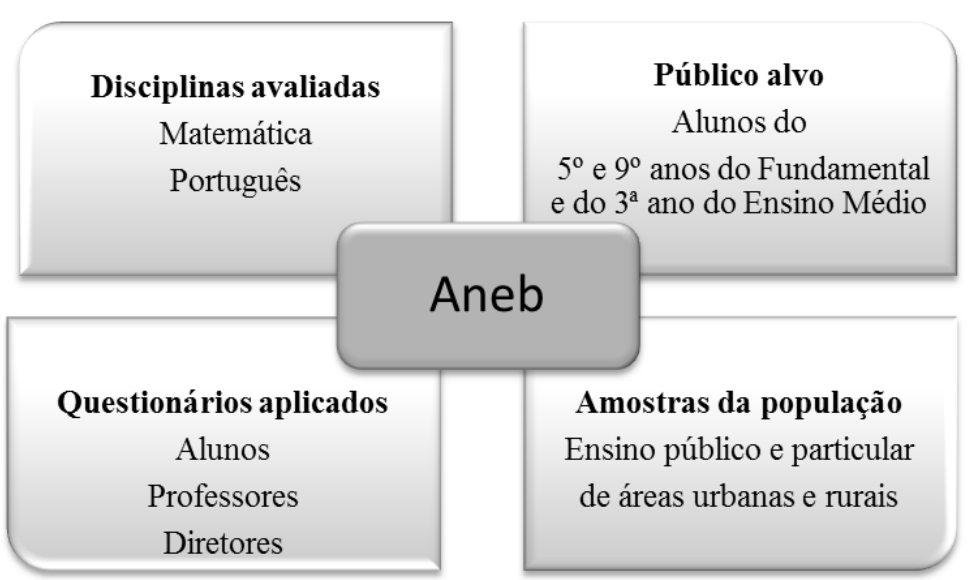

Fonte: Elaborada pelas autoras com base em Inep (2011a).

As disciplinas abordadas nos exames são as de Matemática, com foco na resolução de problemas, e Português, com foco em leitura (Inep, 2011a). O público alvo são alunos pertencentes aos $5^{\circ} \mathrm{e} 9^{\circ}$ anos do ensino fundamental e ao $3^{\circ}$ ano do ensino médio. Apesar de a Prova Brasil e do exame do Saeb serem duas avaliações distintas, o Inep (2011a) afirma que "Todos os alunos do Saeb e da Prova Brasil farão uma única avaliação". Além das avaliações realizadas com os alunos do Ensino Fundamental e Médio, a Aneb aplica, também, questionários socioeconômicos aos participantes da comunidade escolar: alunos, professores e diretores.

\section{Níveis de Desempenho e Competências Leitoras no Saeb}

A Matriz de Referência em Língua Portuguesa das avaliações do Saeb, a qual, segundo Brasil (2008), informa as competências e as habilidades necessárias aos alunos de cada série escolar avaliada, foi desenvolvida, de acordo com Brasil (2008), em 1997, levando-se em conta os conteúdos abordados na escola básica e a análise de professores e de pesquisadores relacionada ao objeto a ser avaliado. Em 2001, segundo Horta-Neto (2007), a matriz foi atualizada devido à propagação dos Parâmetros Curriculares Nacionais (PCN).

O PDE/Prova Brasil (Brasil, 2008) aponta que há duas dimensões nessa matriz. A primeira dimensão trata do "objeto de conhecimento", o qual se divide em seis tópicos relacionados às habilidades dos alunos, a saber: Procedimentos de Leitura; Implicações do Suporte, do Gênero e lou do Enunciador na Compreensão do Texto; Relação entre Textos; Coerência e Coesão no Processamento do Texto; Relações entre Recursos Expressivos e Efeitos de Sentido; Variação Linguística (Brasil, 2008). 
Já a segunda dimensão trata das competências desenvolvidas pelos alunos em cada tópico do objeto de conhecimento, sendo cada um deles divididos em competências nomeadas de "descritivos". Dessa forma, um dos objetos de conhecimento seria o tópico 1 - Procedimentos de leitura - e uma das competências desse tópico seria o descritivo D1 - Localizar informações explícitas em um texto. Entretanto "localizar informações explícitas em um texto” pode ser uma tarefa mais complexa dependendo do nível de dificuldade de um texto. De acordo com Brasil (2008, p. 23), “[...] de um mesmo descritor, podem ser derivados itens de graus de complexidade distintos, tanto do ponto de vista do objeto analisado, o texto, quanto do ponto de vista da tarefa, como as determinações específicas do gênero e da época em que foi produzido".

A Matriz de Referência em Língua Portuguesa diferencia os dois termos "habilidades" e "competências", trazendo a definição de competência, como afirma o documento, baseada em Perrenoud: “[...] capacidade de agir eficazmente em um determinado tipo de situação, apoiando-se em conhecimentos, mas sem se limitar a eles" (Brasil, 2008 , p. 18). Contudo, de acordo com o próprio Perrenoud (1999), definir "competência" não é tarefa fácil, pois: "A palavra tem muitos significados, e ninguém pode pretender dar a definição" (Perrenoud, 1999, p. 19, grifos do autor). Assim sendo, pode-se pensar que, ao usar-se o termo, deve-se apontar o sentido em que ele será utilizado. Em seu livro Construir as competências desde a escola, por exemplo, Perrenoud (1999, p. 21, grifos nossos) afirma: "As competências, no sentido que será utilizado $a q u i$, são aquisições, aprendizados construídos, e não virtualidades da espécie", sendo assim, nesse caso, competência é aquilo que é construído por meio de vivências, de trocas culturais, ou seja, não é inerente ao indivíduo.

Já o termo "habilidade", segundo a Matriz de Referência em Língua Portuguesa, relaciona-se às "competências já adquiridas" (Brasil, 2008, p. 18), ou seja, para a Matriz, a partir do momento em que o indivíduo adquire um conjunto de competências, este passa a ter a habilidade. Ou seja, para adquirir a habilidade da primeira dimensão, o leitor precisa adquirir as competências da segunda. Entretanto, apesar da separação dos conceitos de habilidade e competência feita pela Matriz (Brasil, 2008), o próprio documento mescla os termos quando afirma: "A habilidade indicada por este descritor objetiva reconhecer o efeito de sentido decorrente da escolha de uma determinada palavra ou expressão", visto que, anteriormente, o documento aponta que o descritor, elemento da segunda dimensão, é uma competência.

Dada a complexidade do termo "competência" e sem a pretensão de defini-lo aqui, adotar-se-á a distinção feita por Perrenoud (1999). Neste artigo, em relação à leitura, assume-se o termo no sentido de serem ações adquiridas por um indivíduo para que este possa ter a capacidade de interagir com a leitura, de refletir sobre ela, expressar-se, argumentar. Por exemplo, para que um indivíduo seja capaz de argumentar, ele 
necessita adquirir certas competências em leitura apontadas pelas Matrizes: reconhecer diferentes formas de tratar uma informação na comparação de textos, identificar o conflito gerador do enredo e os elementos que constroem a narrativa, estabelecer relações entre partes de um texto, etc.

$\mathrm{O}$ quadro 1 a seguir apresenta os objetos de conhecimento e as competências a serem desenvolvidas, segundo a Matriz de Referência em Língua Portuguesa, para cada um dos tópicos para o $5^{\circ}$ ano do Ensino Fundamental, dos quais fazem parte quinze competências (descritivos D1 a D15):

\section{Quadro 1 - Matriz de referência do $5^{\circ}$ ano}

\begin{tabular}{|c|c|}
\hline $\begin{array}{c}\text { Primeira } \\
\text { Dimensão }\end{array}$ & Segunda Dimensão \\
\hline $\begin{array}{l}\text { Objetos do } \\
\text { conhecimento }\end{array}$ & Competências \\
\hline $\begin{array}{l}\text { Tópico } 1 \text { - } \\
\text { Procedimentos de } \\
\text { Leitura }\end{array}$ & $\begin{array}{l}\text { D1 - Localizar informações explícitas em um texto. } \\
\text { D3 - Inferir o sentido de uma palavra ou expressão. } \\
\text { D4 - Inferir uma informação implícita em um texto. } \\
\text { D6 - Identificar o tema de um texto. } \\
\text { D11 - Distinguir um fato da opinião relativa a esse fato. }\end{array}$ \\
\hline $\begin{array}{l}\text { Tópico } 2 \text { - } \\
\text { Implicações } \\
\text { do Suporte, do } \\
\text { Gênero e /ou do } \\
\text { Enunciador na } \\
\text { Compreensão do } \\
\text { Texto }\end{array}$ & $\begin{array}{l}\text { D5 - Interpretar texto com auxílio de material gráfico } \\
\text { diverso (propagandas, quadrinhos, foto, etc.). } \\
\text { D9 - Identificar a finalidade de textos de diferentes } \\
\text { gêneros. }\end{array}$ \\
\hline $\begin{array}{l}\text { Tópico } 3 \text { - Relação } \\
\text { entre Textos }\end{array}$ & $\begin{array}{l}\text { D15 - Reconhecer diferentes formas de tratar uma } \\
\text { informação na comparação de textos que tratam do } \\
\text { mesmo tema, em função das condições em que ele foi } \\
\text { produzido e daquelas em que será recebido. }\end{array}$ \\
\hline $\begin{array}{l}\text { Tópico } 4 \text { - } \\
\text { Coerência e Coesão } \\
\text { no Processamento } \\
\text { do Texto }\end{array}$ & $\begin{array}{l}\text { D2 - Estabelecer relações entre partes de um texto, } \\
\text { identificandorepetições ou substituições que contribuem } \\
\text { para a continuidade de um texto. } \\
\text { D7 - Identificar o conflito gerador do enredo e os } \\
\text { elementos que constroem a narrativa. } \\
\text { D8 - Estabelecer relação causa/consequência entre } \\
\text { partes e elementos do texto. } \\
\text { D12 - Estabelecer relações lógico-discursivas presentes } \\
\text { no texto, marcadas por conjunções, advérbios, etc. }\end{array}$ \\
\hline $\begin{array}{l}\text { Tópico } 5 \text { - Relações } \\
\text { entre Recursos } \\
\text { Expressivos e } \\
\text { Efeitos de Sentido }\end{array}$ & $\begin{array}{l}\text { D13 - Identificar efeitos de ironia ou humor em textos } \\
\text { variados. } \\
\text { D14 - Identificar o efeito de sentido decorrente do uso } \\
\text { da pontuação e de outras notações. }\end{array}$ \\
\hline $\begin{array}{l}\text { Tópico } 6 \text { - Variação } \\
\text { Linguística }\end{array}$ & $\begin{array}{l}\text { D10 - Identificar as marcas linguísticas que evidenciam } \\
\text { o locutor e o interlocutor de um texto. }\end{array}$ \\
\hline
\end{tabular}

Fonte: Elaborado pelas autoras com base em Brasil (2008).

Educação \& Realidade, Porto Alegre, v. 39, n. 2, p. 437-462, abr./jun. 2014. 
Já o quadro 2, a seguir, mostra os objetos de conhecimento e as competências a serem desenvolvidas para cada um dos tópicos para o $9^{\circ}$ ano do Ensino Fundamental e para o $3^{\circ}$ ano do Ensino Médio, dos quais fazem parte vinte e uma competências (descritivos D1 a D21). Alguns números dos descritivos variam entre o $5^{\circ}$ ano e o $9^{\circ}$ do Ensino Fundamental e o $3^{\circ}$ do Ensino Médio, porém as competências são as mesmas. Por exemplo: D7, para o $5^{\circ}$ ano do fundamental, requer que o avaliado identifique o conflito gerador do enredo e os elementos que constroem a narrativa, o qual corresponde ao $D 10$ do $9^{\circ}$ ano e do $3^{\circ}$ ano ${ }^{1}$.

\section{Quadro 2 - Matriz de referência para o $9^{\circ}$ ano do Ensino Fundamental e $3^{\circ}$ ano do Ensino Médio}

\begin{tabular}{|c|c|}
\hline $\begin{array}{c}\text { Primeira } \\
\text { Dimensão } \\
\end{array}$ & Segunda Dimensão \\
\hline $\begin{array}{c}\text { Objetos do } \\
\text { conhecimento }\end{array}$ & Competências \\
\hline $\begin{array}{l}\text { Tópico } 1 \text { - } \\
\text { Procedimentos de } \\
\text { Leitura }\end{array}$ & $\begin{array}{l}\text { D1 - Localizar informações explícitas em um texto. } \\
\text { D3 - Inferir o sentido de uma palavra ou expressão. } \\
\text { D4 - Inferir uma informação implícita em um texto. } \\
\text { D6 - Identificar o tema de um texto. } \\
\text { D14 - Distinguir um fato da opinião relativa a esse fato. }\end{array}$ \\
\hline $\begin{array}{l}\text { Tópico } 2 \text { - } \\
\text { Implicações } \\
\text { do Suporte, do } \\
\text { Gênero e/ou do } \\
\text { Enunciador na } \\
\text { Compreensão do } \\
\text { Texto }\end{array}$ & $\begin{array}{l}\text { D5 - Interpretar texto com auxílio de material gráfico } \\
\text { diverso (propagandas, quadrinhos, foto, etc.). } \\
\text { D12 - Identificar a finalidade de textos de diferentes } \\
\text { gêneros. }\end{array}$ \\
\hline $\begin{array}{l}\text { Tópico } 3 \text { - Relação } \\
\text { entre Textos }\end{array}$ & $\begin{array}{l}\text { D20 - Reconhecer diferentes formas de tratar uma } \\
\text { informação na comparação de textos que tratam do mesmo } \\
\text { tema, em função das condições em que ele foi produzido e } \\
\text { daquelas em que será recebido. } \\
\text { D21 - Reconhecer posições distintas entre duas ou mais } \\
\text { opiniões relativas ao mesmo fato ou ao mesmo tema. }\end{array}$ \\
\hline $\begin{array}{l}\text { Tópico } 4 \text { - } \\
\text { Coerência e Coesão } \\
\text { no Processamento } \\
\text { do Texto }\end{array}$ & $\begin{array}{l}\text { D2 - Estabelecer relações entre partes de um texto, } \\
\text { identificando repetições ou substituições que contribuem } \\
\text { para a continuidade de um texto. } \\
\text { D7 - Identificar a tese de um texto. } \\
\text { D8 - Estabelecer relação entre a tese e os argumentos } \\
\text { oferecidos para sustentá-la. } \\
\text { D9 - Diferenciar as partes principais das secundárias em } \\
\text { um texto. } \\
\text { D10 - Identificar o conflito gerador do enredo e os } \\
\text { elementos que constroem a narrativa. } \\
\text { D11 - Estabelecer relação causa/consequência entre partes } \\
\text { e elementos do texto. } \\
\text { D15-Estabelecer relações lógico-discursivas presentes no } \\
\text { texto, marcadas por conjunções, advérbios, etc. }\end{array}$ \\
\hline
\end{tabular}


Bridon; Neitzel

\begin{tabular}{|l|c|}
\hline & $\begin{array}{c}\text { D16 - Identificar efeitos de ironia ou humor em textos } \\
\text { variados. }\end{array}$ \\
Tópico 5 - Relações & D17 - Reconhecer o efeito de sentido decorrente do uso da \\
entre Recursos & pontuação e de outras notações. \\
Expressivos e & D18-Reconhecer o efeito de sentido decorrente da escolha \\
Efeitos de Sentido & de uma determinada palavra ou expressão. \\
& D19 - Reconhecer o efeito de sentido decorrente da \\
& exploração de recursos ortográficos e/ou morfossintáticos. \\
\hline Tópico 6 - Variação & D13 - Identificar as marcas linguísticas que evidenciam o \\
Linguística & locutor e o interlocutor de um texto. \\
\hline
\end{tabular}

Fonte: Elaborado pelas autoras com base em Inep (2011c).

Na Prova Brasil, há dez níveis de desempenho em leitura os quais vão de $0-9$. As escalas usadas para os alunos do $5^{\circ}$ e do $9^{\circ}$ anos do Ensino Fundamental são as mesmas. Segundo Brasil (2008), os níveis alcançados pelos alunos do $5^{\circ}$ ano deveriam ser mais baixos daqueles atingidos pelos alunos do $9^{\circ}$, visto que, de acordo com o próprio documento, alunos do $5^{\circ}$, normalmente, possuem menos competências leitoras do que os do $9^{\circ}$. O documento alerta, assim, para a necessidade de a escola trabalhar a leitura de forma sistemática, a possibilitar que o aluno amplie as competências leitoras a cada ano, em uma escala ascensional que o permitirá, ao final do $9^{\circ}$ ano, não só localizar informações explícitas nos textos mas, principalmente, as implícitas, identificando nuances da língua portuguesa.

Os resultados dessa avaliação possibilitam a oportunidade de conhecerem-se os níveis de desempenho alcançados e, a partir deles, promover ações no âmbito da escola, não só para elevar os índices nacionais, mas, principalmente, para que os alunos cresçam cognitivamente, visto que a leitura é parte primordial na vida acadêmica e profissional de um indivíduo, ampliando, assim, a qualidade da educação básica. De acordo com Castro (2009), anteriormente ao estabelecimento da avaliação educacional em larga escola, a aquisição de conhecimento e das competências básicas por parte dos alunos era medida pelo acesso e pela permanência na escola, isto é, a continuidade do discente no sistema educacional dava mostras de seu desenvolvimento cognitivo. Entretanto, como a própria pesquisadora afirma: "É verdade que a maior permanência nos sistemas educativos traz alguns benefícios, mas não necessariamente significa que os cidadãos estão aprendendo e incorporando os conhecimentos e competências necessários para o seu desenvolvimento profissional e pessoal" (Castro, 2009, p. 6).

O documento do PDE/Prova Brasil (Brasil 2008), ao trazer exemplos de resultados de escolas com o mesmo nível socioeconômico, em que uma escola obteve 133 pontos, mostrando um baixo desempenho, e outra com 208, indica como as políticas e práticas de cada escola conseguem driblar as situações adversas que normalmente minam o trabalho educativo. Nesse caso, as escolas fazem parte da mesma rede de ensino, recebem os mesmos recursos financeiros; os professores, os 
mesmos salários, mas apresentam resultados muito diferentes, evidenciando que as condições de trabalho e o comprometimento do grupo são determinantes para se aumentar a qualidade na educação básica.

A realização da Prova Brasil permite a classificação dos níveis de leitura de cada aluno, possibilitando a identificação da fragilidade do processo de letramento dos sujeitos. Em se tratando dos níveis de 0 a 3 de desempenho em leitura, a pontuação de cada um e as competências necessárias para alcançar esses níveis nos $5^{\circ} \mathrm{e} 9^{\circ}$ anos podem ser observadas no quadro 3 que segue.

\section{Quadro 3 - Pontuação e competências em leitura dos níveis 0 a 3} do $5^{\circ}$ e do $9^{\circ}$ ano

\begin{tabular}{|c|l|}
\hline $\begin{array}{c}\text { Níveis de } \\
\text { desempenho }\end{array}$ & \multicolumn{1}{c|}{ Competências } \\
\cline { 2 - 2 } $\begin{array}{c}\text { Nível 0 } \\
\text { Abaixo de } 125^{2} \\
\text { pontos }\end{array}$ & Não demonstram competências elementares. \\
\hline $\begin{array}{c}\text { Nível 1 } \\
125 \text { a 150 pontos }\end{array}$ & $\begin{array}{l}\text { - localizar informações explícitas em textos; } \\
\text { - identificar o tema de um texto; } \\
\text { - localizar elementos da narrativa como o personagem } \\
\text { principal; }\end{array}$ \\
\hline $\begin{array}{c}\text { Nível } 2 \\
150 \text { a } 175 \text { pontos }\end{array}$ & $\begin{array}{l}\text { Competências anteriores e: } \\
\text { - interpretar texto com auxílio de material gráfico diverso; } \\
\text { - identificar o conflito gerador e finalidade do texto. }\end{array}$ \\
\hline $\begin{array}{c}\text { Nível 3 } \\
175 \text { a } 200 \text { pontos }\end{array}$ & Competências dos níveis 1 e 2. \\
\hline
\end{tabular}

Fonte: Elaborado pelas autoras com base em Inep (2011c; 2011d).

No nível 1, os avaliados trabalham com textos informativos e narrativos curtos (Inep, 2011d). No nível 2, as narrativas as quais fazem parte das avaliações, de acordo com o Inep (2011d), são mais complexas, sendo introduzidos outros gêneros textuais. Nesse nível, além de os discentes possuírem as competências anteriormente destacadas, eles devem inferir informação em texto verbal e não-verbal e relacionar texto e ilustração. Já, no nível 3, segundo o Inep (2011d), as competências necessárias são as presentes nos níveis anteriores, porém estas são voltadas a temáticas e a vocabulários mais complexos. As competências exigidas para que o aluno atinja determinado nível é um apelo para que a escola centre seus esforços na leitura de textos não apenas para localizar informações, mas, principalmente, em ações que busquem formar leitores. À medida que o aluno faz seu percurso escolar, espera-se que ele amplie as competências de leitura, levando-o a alcançar níveis mais altos de desempenho.

Em se tratando dos níveis 4 a 6, a pontuação de cada um desses níveis e as competências necessárias para atingi-los são as mostradas no quadro 4 a seguir. 


\section{Quadro 4 - Pontuação e competências em leitura dos níveis 4 a 6 do $5^{\circ}$ e do $9^{\circ}$ ano}

\begin{tabular}{|c|c|}
\hline \multirow{2}{*}{$\begin{array}{c}\text { Níveis de } \\
\text { desempenho }\end{array}$} & Competências \\
\hline & $5^{\circ}$ e $9^{\circ}$ ano \\
\hline $\begin{array}{c}\text { Nível } 4 \\
200 \text { a } 225 \\
\text { pontos }\end{array}$ & $\begin{array}{l}\text { Competências anteriores e: } \\
\text { - selecionar informações implícitas; } \\
\text { - inferir a informação que provoca efeito de humor no texto; } \\
\text { - inferir o sentido de uma palavra ou expressão; } \\
\text { - estabelecer relação causa/consequência entre partes e } \\
\text { elementos do texto. }\end{array}$ \\
\hline $\begin{array}{l}\text { Nível } 5 \\
225 \text { a } 250 \\
\text { pontos }\end{array}$ & $\begin{array}{l}\text { Competências anteriores e: } \\
\text { - identificar o efeito de sentido provocado pela pontuação; } \\
\text { - distinguir um fato de opinião relativa ao fato; } \\
\text { - identificar a relação lógico-discursiva marcada por elementos } \\
\text { coesivos } \\
\text { - localizar a informação principal do texto ( } 9^{\circ} \text { ano, apenas); } \\
\text { - Diferenciar as partes principais das secundárias em um texto } \\
\text { (9o ano, apenas); } \\
\text { - identificar a tese de um texto e os argumentos que a defendem } \\
\text { (9o ano); } \\
\text { - reconhecer posições distintas entre duas ou mais opiniões } \\
\text { relativas ao mesmo fato ou ao mesmo tema ( } 9^{\circ} \text { ano, apenas); } \\
\text { - reconhecer o efeito de sentido decorrente da escolha de uma } \\
\text { determinada palavra ou expressão ( } 9^{\circ} \text { ano, apenas). }\end{array}$ \\
\hline $\begin{array}{l}\text { Nível } 6 \\
250 \text { e } 275 \\
\text { pontos }\end{array}$ & $\begin{array}{l}\text { Competências anteriores e: } \\
\text { - comparar textos que tratam do mesmo tema; } \\
\text { - reconhecer o efeito de sentido decorrente da exploração de } \\
\text { recursos ortográficos ( } 9^{\circ} \text { ano). }\end{array}$ \\
\hline
\end{tabular}

Fonte: Elaborado pelas autoras com base em Inep (2011c; 2011d).

Para atingir níveis mais altos de conhecimento, a escola precisa inserir textos de variados gêneros, pois os discentes são avaliados no nível 4 a partir de anedotas, fábulas, textos poéticos, ou, ainda, textos com informações científicas. Os narrativos apresentam-se mais complexos e os informativos mais longos. (Inep, 2011d). No nível 5, há a presença de textos narrativos, argumentativos e poéticos cujos conteúdos são mais complexos daqueles presentes nos níveis anteriores, consoante o Inep (2011d). No nível 6, os textos apresentados são mais longos, e há presença de textos poéticos, gráficos, e tabelas. Em relação aos níveis 7 a 9, a pontuação de cada um desses níveis e as competências que fazem parte de cada um deles encontram-se no quadro 5 a seguir. 


\section{Quadro 5 - Pontuação e competências em leitura dos níveis 7 a 8 do $5^{\circ}$ e do $9^{\circ}$ ano}

\begin{tabular}{|c|c|}
\hline \multirow{2}{*}{$\begin{array}{c}\text { Níveis de } \\
\text { desempenho }\end{array}$} & Competências \\
\hline & $5^{\circ}$ e $9^{\circ}$ ano \\
\hline $\begin{array}{l}\text { Nível } 7 \\
275 \text { e } 300 \\
\text { pontos }\end{array}$ & Competências dos níveis 1 a 6. \\
\hline $\begin{array}{l}\text { Nível } 8 \\
300 \text { a } 325 \\
\text { pontos }\end{array}$ & $\begin{array}{l}\text { Competências anteriores e: } \\
\text { - estabelecer relação entre a tese e os argumentos oferecidos } \\
\text { para sustentá-la (9o ano) }\end{array}$ \\
\hline $\begin{array}{l}\text { Nível } 9 \\
325 \text { a } 350 \\
\text { pontos }\end{array}$ & $\begin{array}{l}\text { Competências anteriores e: } \\
\text { - compreender textos mais longos de vocabulário mais } \\
\text { complexo em seu sentido global ( } 9^{\circ} \text { ano). }\end{array}$ \\
\hline
\end{tabular}

Fonte: Elaborado pelas autoras com base em Inep (2011c; 2011d).

Pode-se observar que a exigência vai aumentando e cada nível exige que o aluno tenha adquirido as competências anteriores. A compreensão de textos mais longos, com vocabulário mais complexo pede que a escola trabalhe com textos também da literatura clássica e que explore as nuances da linguagem, como a intenção irônica. Conforme resultados do Saeb/Prova Brasil de 2011 (Brasil, 2012), cuja avaliação foi realizada em 55.924 escolas públicas, a percentagem de alunos do $5^{\circ}$ ano do Ensino fundamental em cada nível de desempenho está distribuída conforme pode ser observado no gráfico 1 a seguir.

\section{Gráfico 1 - Percentagem de alunos do $5^{\circ}$ ano em cada nível de} desempenho

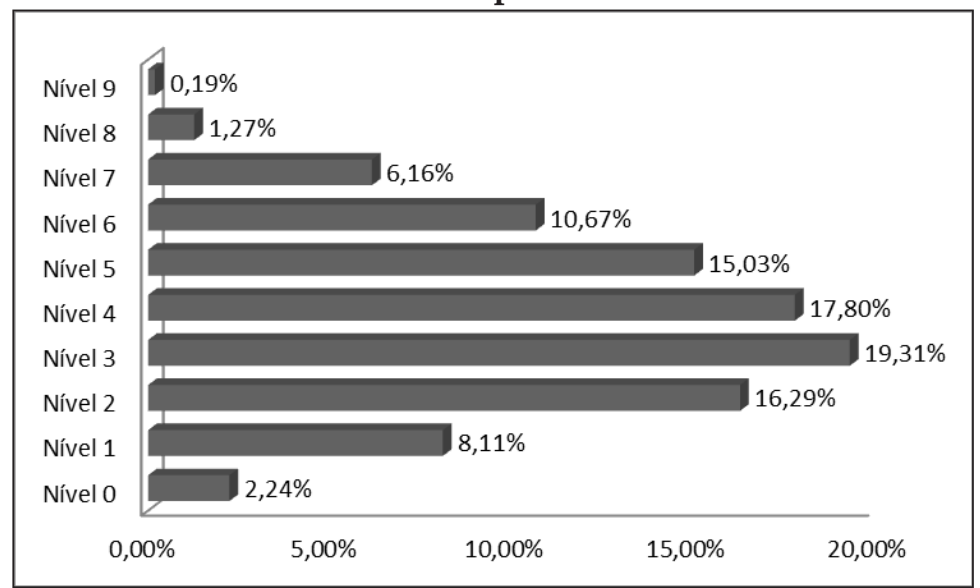

Fonte: Elaborada pelas autoras com base nos dados apresentados por Brasil (2012).

De acordo com o documento PDE/Saeb (Brasil, 2008), não há um consenso entre organizações, estados e municípios em relação ao nível 
adequado de desempenho que os alunos do $5^{\circ}$ e $9^{\circ}$ anos devam alcançar. Entretanto, o mesmo documento afirma que o PDE adotou como adequadas as médias definidas pelo movimento Todos pela Educação: acima de 200 pontos para o $5^{\circ}$ ano do Ensino Fundamental.

Nota acima de 200 pontos para o $5^{\circ}$ ano coloca o avaliado a partir do nível 4 de desempenho, o que significa, ao somar-se a percentagem de alunos avaliados de acordo com os resultados do Saeb/Prova Brasil 2011 (Brasil, 2012), que 54,05\% dos alunos do $5^{\circ}$ ano, na média nacional, encontram-se no nível 4 ou acima de desempenho em leitura. Consequentemente, 45,95\% dos alunos, desse nível escolar, estão abaixo do nível considerado ideal, visto que $2,24 \%$ dos alunos encontram-se no nível 0, 8,11\%, no nível 1, 16,29\% no nível 2 e 19,31\% no nível 3, conforme pode observar-se no gráfico 1 anterior. Percebe-se, assim, que um número considerável de alunos do $5^{\circ}$ ano já iniciam seus estudos no terceiro e quarto ciclos do Ensino Fundamental com defasagens no desempenho em leitura. É importante atentar, aqui, para a importância da leitura na vida do sujeito dentro e fora da escola, por isso é nesta que os alunos necessitam adquirir as competências leitoras para que possam recorrer à leitura em suas diferentes manifestações.

Em se tratando do $9^{\circ}$ ano, de acordo com os resultados apresentados pelo Saeb/Prova Brasil de 2011 (Brasil, 2012), a percentagem de discentes em cada nível de desempenho está dividida conforme pode ser observado no gráfico 2 que segue.

\section{Gráfico 2 - Percentagem de alunos do $9^{\circ}$ ano em cada nível de} desempenho

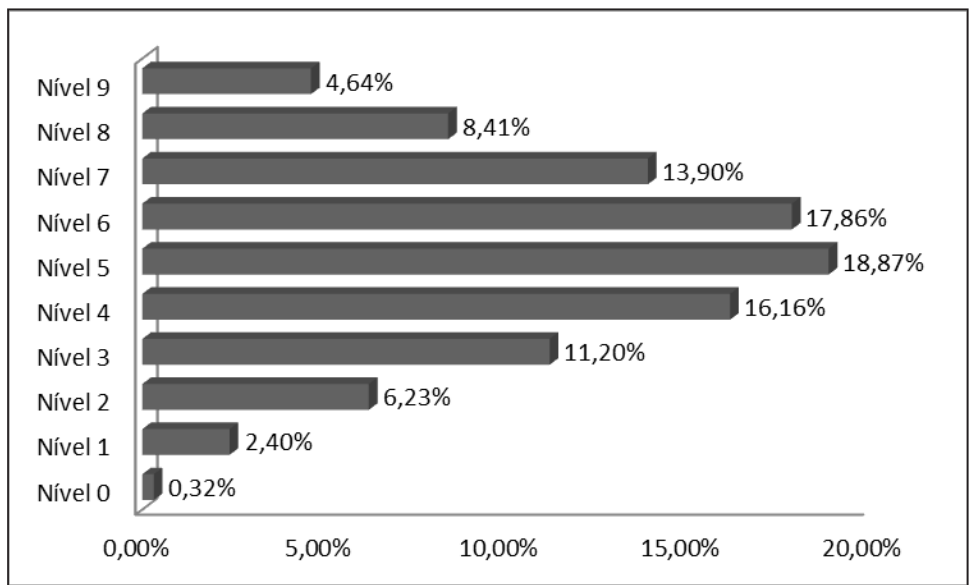

Fonte: Elaborada pelas autoras com base nos dados apresentados por Brasil (2012).

De acordo com o documento PDE/Saeb (Brasil, 2008), a média considerada adequada para o $9^{\circ}$ ano é acima de 275 pontos. Nota acima de 275 coloca o discente no nível 7 de desempenho em Língua Portuguesa. Segundo os resultados divulgados pelo Inep (Brasil, 2012),

Educação \& Realidade, Porto Alegre, v. 39, n. 2, p. 437-462, abr./jun. 2014. 451 Disponível em: <http://www.ufrgs.br/edu_realidade> 
26,95\% dos alunos do $9^{\circ}$ (média nacional), encontram-se nesse nível de desempenho ou acima. Ou seja, $73,04 \%^{3}$ dos alunos brasileiros avaliados, encontram-se abaixo do nível esperado em desempenho de leitura no cenário nacional, já que, como pode ser observado no gráfico 2 anterior, $0,32 \%$ encontram-se no nível $0 ; 2,40 \%$ no nível $1 ; 6,23 \%$ no nível 2; 11,20\% no nível 3; 16,16\%; no nível 4; 18,87\% no nível 5 e, finalmente, $17,86 \%$ dos discentes no nível 6.

Conforme o Inep (2011e), às habilidades do Ensino Médio acrescentam-se as do Fundamental. A diferença maior entre um nível de escolaridade e o outro é o nível de complexidade dos textos. Dessa forma, competências em leitura não adquiridas no Ensino Fundamental será o calcanhar de Aquiles do Médio.

Os alunos do $9^{\circ}$ ano encontram-se nas portas do Ensino Médio, e, ainda, faltam, a muitos deles, desenvolver competências em leitura importantes para seguir a caminhada, a saber: estabelecer relação causa/consequência entre partes e elementos do texto; inferir informações; distinguir fato de opinião; diferenciar partes principais de secundárias; localizar a informação principal do texto; identificar efeito de sentido; identificar tese e argumentos presentes em um texto; reconhecer posições distintas em relação a um tema; comparar textos que tratem do mesmo tema.

Pode-se inferir, aqui, que a qualidade da educação básica depende da escola possibilitar aos alunos lidar com textos que os levem a desenvolver essas competências, ampliando, assim, seus modos de ler. A partir do nível 5, os alunos do $9^{\circ}$ ano, por exemplo, entram em contato com textos narrativos, argumentativos e poéticos mais complexos. Para alcançar o nível 7, os discentes necessitam estar familiarizados com gêneros variados de textos e, também, com a literatura clássica, como já afirmado anteriormente. Assim, para que eles desenvolvam essas competências e possam lidar com esses tipos de textos, os discentes necessitam não apenas ter contato com eles de maneira informal, mas de forma sistematizada, para que eles possam "[...] estabelecer vínculos cada vez mais estreitos entre o texto e outros textos, construindo referências sobre o funcionamento da literatura e entre esta e o conjunto cultural [...]" (Brasil, 1998, p. 71).

Muitas dessas competências são possíveis de serem desenvolvidas a partir da leitura do texto literário, visto que, ao lidar com o texto em sua totalidade - lê-lo na íntegra, refletir sobre ele, discutir sobre ele, viajar em suas entrelinhas -, o aluno-leitor pode passar a estabelecer relações sobre os acontecimentos, a inferir, a reconhecer opiniões que diferem dentro de um texto, a perceber os elementos mais significativos, a embrenhar-se em seus significados mais ocultos em busca de construir sentido.

Em relação ao $3^{\circ}$ ano do Ensino Médio, de acordo com o Inep (2011e), os níveis da escala de desempenho das provas do Saeb em Lín- 
gua Portuguesa são distribuídos em seis níveis de desempenho. De acordo com o Inep (2011e), o número de competências leitoras que fazem parte desse nível de escolaridade parece ser menor do que o número presente na escala de desempenho dos $5^{\circ}$ e $9^{\circ}$ anos do Ensino Fundamental. Contudo, isso acontece porque é esperado que os alunos do Ensino Médio tenham adquirido as competências presentes na escala de desempenho do Fundamental.

No quadro 6 que segue, podem-se observar a pontuação e as competências que fazem parte dos níveis de desempenho de 1 a 3 no $3^{\circ}$ ano do Ensino Médio.

\section{Quadro 6 - Pontuação e competências em leitura dos níveis 1 a 3} do $3^{\circ}$ ano do Ensino Médio

\begin{tabular}{|c|c|}
\hline \multirow{2}{*}{$\begin{array}{c}\text { Níveis de } \\
\text { desempenho }\end{array}$} & Competências \\
\hline & $3^{\circ}$ ano do Ensino Médio \\
\hline $\begin{array}{l}\text { Nível } 1 \\
150 \text { a } 175 \\
\text { pontos }\end{array}$ & - localizar informações explícitas. \\
\hline $\begin{array}{l}\text { Nível } 2 \\
175 \text { a } 250 \\
\text { pontos }\end{array}$ & $\begin{array}{l}\text { Competência anterior e: } \\
\text { - distinguir fato de opinião; } \\
\text { - identificar a finalidade de texto informativo. }\end{array}$ \\
\hline $\begin{array}{l}\text { Nível } 3 \\
250 \text { a } 300 \\
\text { pontos }\end{array}$ & $\begin{array}{l}\text { Competências anteriores e: } \\
\text { - inferir o sentido de palavras de uso cotidiano e de maior } \\
\text { complexidade; } \\
\text { - identificar informação implícita; } \\
\text { - identificar o tema; } \\
\text { - interpretar texto publicitário com auxilio gráfico; } \\
\text { - estabelecer relações entre tese e argumentos em textos; } \\
\text { - identificar efeito da exploração de recursos ortográficos/ } \\
\text { morfossintáticos. }\end{array}$ \\
\hline
\end{tabular}

Para alcançar os níveis 1 e 2, os alunos do $3^{\circ}$ ano do Ensino Médio devem ser capazes de lidar com fragmentos de textos narrativos simples. No nível 3, as competências avaliadas são a partir de textos narrativos simples, de textos informativos e poéticos, textos de jornal de baixa complexidade e textos publicitários com auxilio gráfico (Inep, 2011e).

Em se tratando dos níveis de desempenho de 4 a 6 , a pontuação e as competências que englobam esses níveis são distribuídas conforme pode ser observado no quadro 7 a seguir. 


\section{Quadro 7 - Pontuação e competências em leitura dos níveis 4 a 6 do $3^{\circ}$ ano}

\begin{tabular}{|c|c|}
\hline \multirow{2}{*}{$\begin{array}{c}\text { Níveis de } \\
\text { desempenho }\end{array}$} & Competências \\
\hline & $3^{\circ}$ ano do Ensino Médio \\
\hline $\begin{array}{c}\text { Nível } 4 \\
300 \text { a } 350\end{array}$ & $\begin{array}{l}\text { Competências anteriores e: } \\
\text { - interpretar texto, diferenciando informação principal de } \\
\text { secundária; } \\
\text { - identificar a finalidade de textos; } \\
\text { - reconhecer diferentes formas de tratar a informação em textos } \\
\text { sobre o mesmo tema; } \\
\text { - estabelecer relações de continuidade, identificando repetições } \\
\text { ou retomadas anafóricas; } \\
\text { - identificar a tese de um texto; } \\
\text { - identificar conflito gerador do enredo e elementos que } \\
\text { constroem a narrativa; } \\
\text { - estabelecer relações lógico-discursivas pelo conhecimento } \\
\text { referente aos processos de formação de palavras; } \\
\text { - identificar marcas linguísticas, diferenciando nível formal de } \\
\text { informal de linguagem e faixa etária do locutor. }\end{array}$ \\
\hline $\begin{array}{c}\text { Nível } 5 \\
350 \text { a } 375\end{array}$ & $\begin{array}{l}\text { Competências anteriores e: } \\
\text { - identificar posições distintas entre duas opiniões sobre o } \\
\text { mesmo fato. }\end{array}$ \\
\hline $\begin{array}{c}\text { Nível } 6 \\
375 \text { ou acima }\end{array}$ & $\begin{array}{l}\text { Competências anteriores e: } \\
\text { - reconhecer diferentes formas de tratar a informação em texto } \\
\text { sobre o mesmo tema; } \\
\text { - estabelecer relações entre tese e argumentos; } \\
\text { - estabelecer relações entre causa/consequência entre partes e } \\
\text { elementos do texto; } \\
\text { - identificar efeitos de ironia ou humor; } \\
\text { - identificar o sentido de efeito decorrente da escolha de uma } \\
\text { palavra ou expressão; } \\
\text { - identificar o efeito de sentido decorrente do uso da pontuação; } \\
\text { - identificar marcas linguísticas de um grupo social. }\end{array}$ \\
\hline
\end{tabular}

Fonte: Elaborado pelas autoras com base em Inep (2011c; 2011e).

No nível 4, segundo o Inep (2011e), os alunos são capazes de lidar com textos mais longos e complexos, com textos poéticos, com contos, com textos dissertativo-argumentativos e de divulgação científica. No nivel 5, os discentes lidam com textos mais complexos, formais e informais, com informações quantitativas, de paródias, fábulas modificadas e fragmentos de capítulos de livro (Inep, 2011e). No nível 6, os alunos são capazes de lidar com textos mais longos e complexos, com textos poéticos, com tirinhas, dentre outros.

Segundo os resultados do Saeb/Prova Brasil de 2011, os alunos do $3^{\circ}$ ano do Ensino Médio de 3.392 escolas públicas e particulares, em escala nacional, encontram-se, em média, no nível 3 de desempenho, visto que a média nacional alcançada foi de 267,63. (Brasil, 2012). A média considerada ideal definida pelo movimento Todos pela Educação (2012) 
para o Ensino Médio é de 300 pontos, nível 4 de desempenho. Segundo dados de Todos pela Educação (2012), 29,2\% dos alunos do Ensino Médio encontram-se no nível 4 ou acima, ou seja, 70,8\% dos alunos estão abaixo do nível esperado de desempenho em leitura ${ }^{4}$. Essa constatação reforça a premissa de que a qualidade na educação básica depende de um trabalho voltado à leitura em uma abordagem interdisciplinar. A leitura pode interferir na construção da subjetividade do leitor, ao mesmo tempo em que se afirma como instrumento de democratização do conhecimento e de inclusão social.

É relevante relembrar, aqui, que os alunos já chegam ao $1^{\circ}$ ano do Ensino Médio com defasagem em competências leitoras, visto que, como afirmado anteriormente, $73,04 \%$ dos alunos do $9^{\circ}$ ano encontram-se abaixo do nível esperado, prejudicando seu desenvolvimento nas séries finais da educação básica. Para melhorar a qualidade da educação básica é essencial que a escola promova atividades que os levem a desenvolver competências como: saber inferir; identificar informação implícita; estabelecer relações entre tese e argumentos; reconhecer diferentes formas de tratar um mesmo assunto; estabelecer relações lógico-discursivas - competências possíveis de serem adquiridas quando o aluno-leitor é levado a mergulhar no texto.

\section{O Processo Cognitivo e as Competências em Leitura}

As avaliações do Saeb concentram-se em avaliar a proficiência do leitor por meio de questões focadas no que o leitor é capaz de fazer com o texto. Elas averiguam a capacidade do aluno em reconhecer, identificar, estabelecer, diferenciar, interpretar elementos do texto (Bonamino; Coscarelli; Franco, 2002). Segundo Ferraz e Belhot (2010), anteriormente aos estudos de Benjamin Bloom sobre a classificação dos objetivos da educação, acreditava-se que obter um melhor desempenho na escola ficava na dependência das experiências do aluno fora da escola. No entanto, de acordo com Ferraz e Belhot (2010), por meio dos estudos de Bloom et al. (1988), se alunos tivessem as mesmas experiências externas, as diferenças de nível de conhecimento ainda prosseguiriam, visto que, para Bloom e sua equipe, a diferença na aprendizagem ficaria por conta das estratégias utilizadas no âmbito educacional e os estímulos recebidos para o desenvolvimento cognitivo do aluno (Ferraz; Belhot, 2010).

De acordo com Bloom et al. (1988), a estrutura do processo cognitivo, com base na taxionomia de objetivos educacionais, envolve as categorias apresentadas na figura 4 que segue: 
Figura 4 - Estrutura do Processo Cognitivo com Base na Taxionomia de Bloom

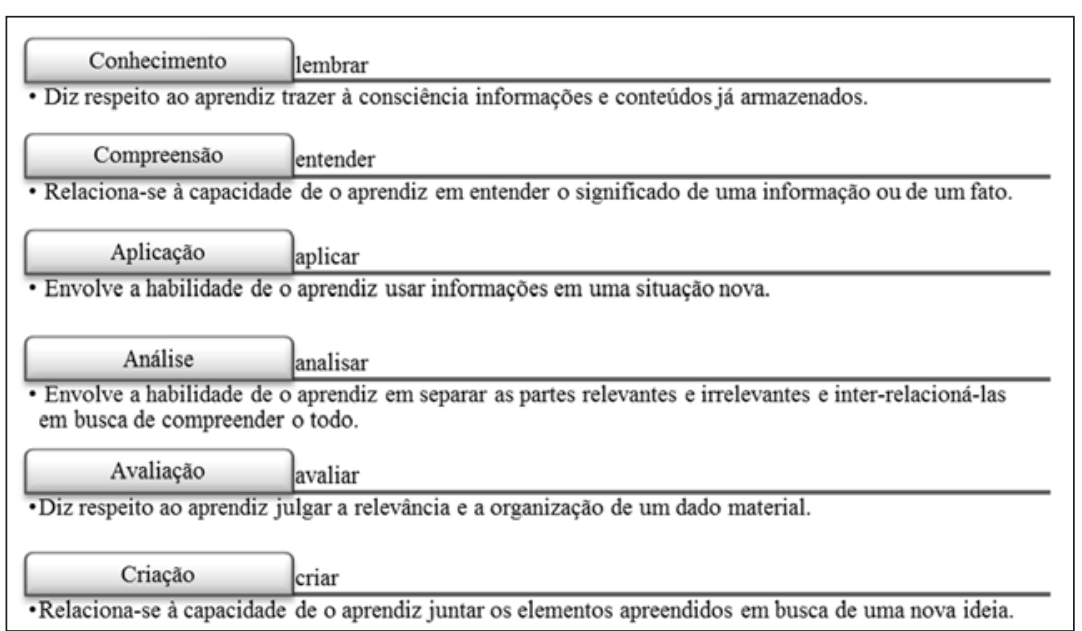

Fonte: Elaborada pelas autoras com base em Bloom et al. (1988).

Conforme Ferraz e Belhot (2010), cada uma dessas categorias envolve verbos que a suporta ${ }^{5}$. Assim sendo, conforme os verbos utilizados em cada estrutura do processo cognitivo da taxionomia, a frequência dos verbos utilizados nas competências em leitura nas avaliações do Saeb pode ser distribuída conforme a tabela 2 a seguir.

\section{Tabela 2 - Verbos das competências em leitura do Saeb na estrutura do processo cognitivo ${ }^{6}$}

\begin{tabular}{llllll}
\hline Lembrar & Entender & Aplicar & Analisar & Avaliar & Criar \\
\hline Reconhecer(5) & Reconhecer(5) & Interpretar(1) & Identificar(6) & Interpretar(1) & Estabelecer(4) \\
\hline Identificar(6) & Interpretar(1) & & Distinguir(1) & & \\
Distinguir(1) & Inferir(2) & & Inferir(2) & & \\
Localizar(1) & Distinguir(1) & & Localizar(1) & & \\
& Identificar(6) & & Diferenciar(1) & & 4vezes \\
13vezes & 15vezes & 1vez & 11 vezes & 1vez & Inep (2011c).
\end{tabular}

Fonte: Elaborada pelas autoras com base em Ferraz e Belhot (2010) e Inep (2011c).

Como pode ser observado na tabela 2 anterior, as matrizes de referência do Saeb concentram-se nas categorias conhecimento, compreensão e análise. Quatro verbos fazem parte da categoria conhecimento (reconhecer, identificar, distinguir e localizar) ${ }^{7}$, os quais aparecem em 13 competências em leitura, cujo intuito é avaliar a capacidade de os alunos em lembrar informações e conteúdos obtidos. A categoria compreensão, a qual avalia o que o aluno entendeu dos conteúdos, traz cinco verbos: reconhecer, interpretar, inferir, distinguir, identificar, os quais aparecem em 15 competências nas matrizes do Saeb. Já a catego- 
ria análise, a qual avalia se os alunos possuem a habilidade de separar o que é ou não importante e relacionar a partes que fazem parte de certa estrutura, as matrizes do Saeb trazem 11 competências presentes nos verbos identificar, distinguir, inferir, localizar e diferenciar.

Já as categorias aplicação, avaliação e criação encontram-se bem menos presentes nas matrizes do Saeb. Em relação à aplicação, apenas o verbo interpretar entra nessa categoria, o qual aparece em uma competência. Na categoria avaliação, as matrizes do Saeb avaliam se o aluno tem a capacidade de fazer julgamentos quando exige competências que envolvem o verbo interpretar, presente uma vez. Em se tratando da Criação, o Saeb avalia se o aluno tem a capacidade de juntar elementos para elaborar um novo, quando traz competências com o verbo estabelecer, presente quatro vezes.

Nessa perspectiva, o Saeb preocupa-se mais em avaliar se o aluno é capaz de lembrar, entender e analisar, abrangendo três das seis categorias da estrutura do processo cognitivo da taxionomia de Bloom, conforme mostra a figura 5 que segue.

\section{Figura 5 - Categorias da Taxionomia de Bloom mais presentes nas avaliações em leitura do Saeb}

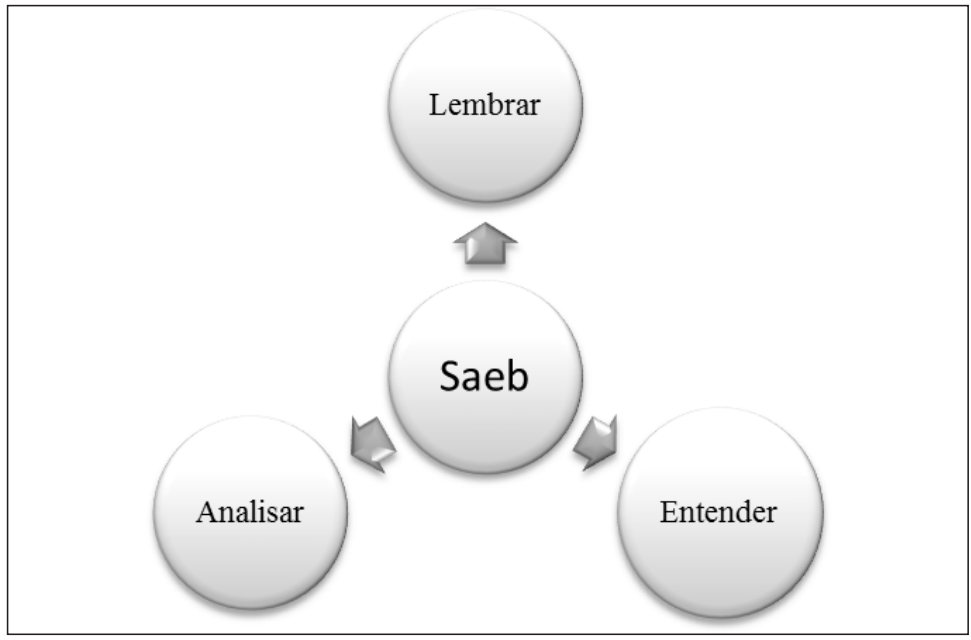

Fonte: Elaborada pelas autoras para fins de pesquisa.

Em relação à grande presença da categoria compreensão (entender) nas matrizes do Saeb, a qual avalia a capacidade dos alunos em compreender fenômenos, é importante ter em mente que, para Bloom et al. (1988), a compreensão é o nível mais baixo de entendimento. Assim sendo, não pode ser este o propósito único do ensino: levar os aprendizes a entender o significado de uma informação ou de um fato. Segundo os autores, a compreensão diz respeito “[...] a um tipo de entendimento ou apreensão tal que o indivíduo conhece o que está sendo comunicado 
e pode fazer uso do material ou ideia que está sendo comunicada, sem necessariamente relacioná-la a outro material ou perceber suas implicações mais completas" (Bloom et al., 1988, p. 175). Constatamos, assim, que as matrizes do Saeb não focam na habilidade de o discente aplicar seus conhecimentos em novas situações, tampouco em sua capacidade de julgar a relevância de uma informação quando deixa de lado competências que envolvam a categoria "avaliação".

\section{Considerações Finais}

O docente é a figura que tem contato direto com o leitor em formação. As avaliações, as escalas de desempenho, as matrizes, os resultados e o que eles significam apontam caminhos que o docente pode seguir na tentativa de melhorar o quadro do leitor em formação e, consequentemente, a qualidade da educação básica. Hoje, segundo Castro (2009), o que se quer de forma mais complexa é "[...] construir e valorizar a boa escola pública, agora democrática e para todos" (Castro, 2009, p. 7), mas, para isso, é necessário prestar atenção aos resultados do sistema de avaliação em busca dessa melhoria, desde o macro até o micro, ou seja, não só todas as instâncias do governo (federal, estadual, municipal), mas também os profissionais da educação diretamente ligados à escola, sendo o docente uma das principais figuras desse processo.

Segundo Oliveira (2011), as políticas públicas de avaliação aplicadas no Brasil podem passar a nortear as práticas de sala de aula. Para a autora, uma visão técnica da escola faz com que sua missão volte-se, por exemplo, ao alcance de metas do Ideb. É preciso, assim, atentar para a preocupação em apenas atingir essas metas. As competências do leitor não podem girar em torno de lembrar, entender e analisar. O leitor em formação precisa ser levado a aplicar, a avaliar e a criar - habilidades importantes para sua vida dentro e fora da escola.

Para que o leitor em formação caminhe em direção a ser um leitor competente, ele necessita adquirir, durante sua permanência no âmbito escolar, as competências em leitura discutidas até aqui. Ao adquirir essas competências, o leitor em formação poderá lidar com uma variedade de textos em sua totalidade. Não se pode ter a visão reducionista indicada por Oliveira (2011) que volta o ensino para a conquista de médias. Entretanto, podem-se usar os caminhos apontados pelas avaliações para se construir leitores. $\mathrm{O}$ aluno precisa ser leitor para que possa lidar com a leitura em seus diferentes contextos: na escola, na universidade, na rua, no trabalho. Seja leitura por prazer, seja leitura por obrigação - ele precisa estar preparado. A leitura está em todos os lugares, em todos os contextos, em todos os cursos, em todas as disciplinas.

A partir das escolhas do que ler e como ler com seus alunos, um docente pode levar seus discentes a desenvolver naturalmente as competências em leitura. Quando um texto é bom, ele pode levar à fruição, 
possibilitando que o leitor vá muito além da decodificação, reagindo a ele, desenvolvendo, assim, suas competências leitoras. O leitor, dessa forma, passará a inferir, a construir sentido, a estabelecer conexões entre textos e conhecimento de mundo. Jouve (2010), ao abordar o que Barthes fala sobre textos de prazer e textos de deleite, aqueles que levam a fruição: afirma: “[...] os textos de prazer são aqueles que, ao se inscreverem em uma cultura, são relativamente previsíveis, fáceis de ler e 'confortáveis'. Os textos de deleite são aqueles que incomodam e perturbam o leitor, mas que, por isso mesmo, marcam-no muito mais profundamente" (Jouve, 2010, p. 210, grifos do autor). Para o leitor em formação, é crucial que ele adquira as competências em leitura por meio do ato de ler em si, embrenhando-se em textos que o leve muito além do explícito.

Em face da problemática aqui apresentada sobre as competências de leitura necessárias ao aluno da educação básica - um exercício de compreensão ampliada dos complexos processos que se efetivam no campo das políticas de avaliação, em especial no que diz respeito à formação de jovens leitores -, enfatizamos que a escola precisa criar estratégias para preparar esses jovens para a leitura e a escrita, visto que ela tem se revelado frágil nessa tarefa. A leitura é um bem cultural e como tal possui um valor simbólico que precisa ser discutido. As políticas públicas estão, com os programas de distribuição de livros, ampliando o acesso do leitor ao livro e a escola não pode ficar à margem desse processo.

Ezequiel Theodoro da Silva (2012), ao analisar a pesquisa Retratos de leitura no Brasilnos anos 2001, 2008 e 2012, enfatiza que "[...] a escola, através do processo de alfabetização e de dinâmicas de letramento, é a principal agência responsável pelo adentramento - e talvez permanência - das pessoas no mundo da escrita" (Silva, 2012, p. 111). Essa constatação apresenta a importância do papel do professor como mediador privilegiado na formação do leitor. Dessa forma, fica evidente que, ao falarmos de leitura no Brasil, precisamos voltar-nos à instituição escolar porque ela é, não única, mas determinante na constituição e desenvolvimento de comportamentos leitores e está relacionada diretamente com a forma como a escola concebe a leitura, como ela é tratada em sala de aula.

\section{Notas}

1 Há um erro de digitação na matriz, nos exemplos e comentários de questões do $9^{\circ}$ ano no sítio do Inep (2011c). No documento Matrizes de Referências: Língua Portuguesa, no tópico I - Procedimentos de Leitura -, há o descritivo D11 - Distinguir um fato da opinião relativa a esse fato, e, no tópico IV - Coerência 
e Coesão no Processamento do Texto-, há, também, o descritivo D11 com o título: Estabelecer relação causa/consequência entre partes e elementos do texto. Nas matrizes de referência do $9^{\circ}$ ano, assim, não há o descritivo D14. Já, nos documentos de exemplos e comentários de questões dessa mesma turma, o descritivo D11 é nomeado D14. Neste trabalho, segue-se a nomeação dada por Brasil (2008) - descritivo D11 - Estabelecer relação causa/consequência entre partes e elementos do texto e D14 - Distinguir um fato da opinião relativa a esse fato.

2 A pontuação trazida pela Descrição dos Níveis da Escala de Desempenho de Língua Portuguesa do $5^{\circ}$ e $9^{\circ}$ anos do Ensino Fundamental e do $3^{\circ}$ ano do Médio (ver Inep 2011d e 2011e) misturam a pontuação de um nível com outro, podendo causar problemas na classificação quando o avaliado marcar 125 pontos, por exemplo, podendo encontrar-se no nível 0 ou 1 de desempenho.

3 Ao somarem-se os resultados por nível de proficiência divulgados por Brasil (2012) para o $9^{\circ}$ ano em Língua Portuguesa, a soma das percentagens não resulta em $100 \%$, ficando em $99,99 \%$.

4 Até o momento, não há disponibilidade de dados relacionados à percentagem de alunos por nível de proficiência em Língua Portuguesa do Ensino Médio pelo Inep.

5 Para a lista de verbos de cada categoria ver Ferraz e Belhot (2010).

6 Os números que aparecem ao lado de cada verbo indicam o número de vezes em que eles aparecem na Matriz de referência para o $9^{\circ}$ ano do Ensino Fundamental e $3^{\circ}$ ano do Ensino Médio.

$7 \mathrm{O}$ verbo localizar foi relacionado ao verbo apontar.

\section{Referências}

BLOOM, Benjamin Samuel et al. Taxionomia de Objetivos Educacionais: domínio cognitivo. Tradução de Flávia Maria Sant’Anna. 9. ed. Rio de Janeiro: Globo, 1988.

BONAMINO, Alicia; COSCARELLI, Carla; FRANCO, Creso. Avaliação e Letramento: concepções de aluno letrado subjacentes ao Saeb e ao PISA. Educação \& Sociedade, Campinas, v. 23, n. 81, p. 91-113, dez. 2002.

BRASIL. Projeto de lei $n^{\circ}$ Aprova o Plano Nacional de Educação para o decênio 2011-2020, e dá outras providências. 2010. Disponível em: <http://portal. mec.gov.br/index.php?option=com_content\&view=article\&id=16478\&Item id=1107>. Acesso em: 6 out. 2012.

BRASIL. Ministério da Educação. Secretaria de Educação Fundamental. Parâmetros Curriculares Nacionais: terceiro e quarto ciclos do ensino fundamental: língua portuguesa. Brasília: MEC/SEF, 1998.

BRASIL. Portaria No 931, de 21 de março de 2005. Diário Oficial da União, n. 55, seção 1, 22/03/2005. Disponível em: <http://download.inep.gov.br/download/ saeb/2005/portarias/Portaria931_NovoSaeb.pdf>. Acesso em: 18 jul. 2012

BRASIL. Ministério da Educação. PDE: Plano de Desenvolvimento da Educação: Prova Brasil: ensino fundamental: matrizes de referência, tópicos e descritores. Brasília: MEC, SEB; Inep, 2008.

BRASIL. Ministério da Educação. Instituto Nacional de Estudos e Pesquisas Educacionais Anísio Teixeira. Diretoria de Avaliação da Educação Básica. 
SAEB/Prova Brasil 2011 - primeiros resultados. 2012. Disponível em: <http:// download.inep.gov.br/educacao_basica/prova_brasil_saeb/resultados/2012/ Saeb_2011_primeiros_resultados_site_Inep.pdf $>$. Acesso em: 30 mar. 2013

CASTRO, Maria Helena. Guimarães de. Sistemas de Avaliação da Educação no Brasil: avanços e novos desafios. São Paulo em Perspectiva, São Paulo, v. 23, n. 1, p. 5-18, jan./jun. 2009.

ECO, Umberto. Os Limites da Interpretação. Tradução de Pérola de Carvalho. 2. ed. 2. reimp. São Paulo: Perspectiva, 2010.

FERRAZ, Ana Paula do Carmo Marcheti; BELHOT, Renato Vairo. Taxonomia de Bloom: revisão teórica e apresentação das adequações do instrumento para definição de objetivos instrucionais. Gestão \& Produção, São Carlos, v. 17, n. 2, p. 421-431, 2010.

GAGNÉ, Ellen D.; YEKOVICH, Carol Walker; YEKOVICH, Frank R. The Cognitive Psychology of School Learning. 2. ed. New York, USA: Harper Collins, 1993.

HORTA-NETO, João Luiz. Um Olhar Retrospectivo sobre a Avaliação Externa no Brasil: das primeiras medições em educação até o SAEB de 2005. Revista Iberoamericana de Educación, n. 42/5, 2007.

INEP. Instituto Nacional de Estudos e Pesquisas Educacionais Anísio Teixeira. Prova Brasil e Saeb: Semelhanças e diferenças. 2011a. Disponível em: <http:// portal.inep.gov.br/web/prova-brasil-e-saeb/semelhancas-e-diferencas $>$. Acesso em: 1 jan. 2013.

INEP. Instituto Nacional de Estudos e Pesquisas Educacionais Anísio Teixeira. Características do Saeb. 2011b. Disponível em: <http://portal.inep.gov.br/web/ guest/caracteristicas-saeb>. Acesso em: 20 jul. 2012.

INEP. Instituto Nacional de Estudos e Pesquisas Educacionais Anísio Teixeira. Matrizes de Referência: Língua Portuguesa. In: Área de documentos da Prova Brasil e Saeb. Matrizes de Referência: Língua Portuguesa (Arquivos compactados no formato Zip). Inep 2011c. Disponível em: <http://portal.inep.gov.br/web/ prova-brasil-e-saeb/downloads $>$. Acesso em: 1 jan. 2013.

INEP. Instituto Nacional de Estudos e Pesquisas Educacionais Anísio Teixeira. Descrição dos Níveis da Escala de Desempenho de Língua Portuguesa - Saeb: $5^{\circ}$ e $9^{\circ}$. Ano do Ensino Fundamental. 2011d. Disponível em: <http://download. inep.gov.br/educacao_basica/prova_brasil_saeb/escala/2011/escala_desempenho_portugues_fundamental.pdf $>$. Acesso em: 1 jan. 2013.

INEP. Instituto Nacional de Estudos e Pesquisas Educacionais Anísio Teixeira. Descrição dos Níveis de Escala de Desempenho de Língua Portuguesa - SAEB: $3^{\text {a }}$ série do Ensino Médio. 2011e. Disponível em: <http://download.inep.gov. br/educacao_basica/prova_brasil_saeb/escala/2011/escala_desempenho_lingua_portuguesa_medio.pdf $>$. Acesso em: 2 jan. 2013.

JOUVE, Vincent et al. Entrevista com Vincent Jouve, autor de A leitura. Tradução de Brigitte Hervot. Leitura em Revista, Cátedra UNESCO de Leitura PUC-Rio, n. 1, out. 2010 .

LIBÂNEO, José Carlos. Sistema de Ensino, Escola, Sala de Aula: onde se produz a qualidade das aprendizagens? In: LOPES, Alice Casimiro; MACEDO, Elizabeth (Org.). Políticas de Currículo em Múltiplos Contextos. São Paulo: Cortez, 2006. (Série Cultura, Memória e Currículo: volume 7).

LIBÂNEO, José Carlos. Alguns Aspectos da Política Educacional do Governo Lula e sua Repercussão no Funcionamento das Escolas. Revista HISTEDBR On-line, Campinas, n. 32, p. 168-178, dez. 2008. 
OLIVEIRA, Ana Paula de Matos. Prova Brasil como Política de Regulação da Rede Pública do Distrito Federal. 2011. 274f. Dissertação (Mestrado em Educação) - Programa de Pós-Graduação em Educação, Universidade de Brasília, Brasília, 2011.

PERRENOUD, Philippe. Construir as Competências desde a Escola. Tradução de Bruno Charles Magne. Porto Alegre: Artes Médicas, 1999.

SILVA, Ezequiel Theodoro da. A Escola e a Formação de Leitores. In: FAILLA, Zora (Org.). Retratos da leitura no Brasil 3. São Paulo: Imprensa oficial do Estado de São Paulo: Instituto Pró-Livro, 2012.

TODOS PELA EDUCAÇ̃̃O. Dados do Brasil. 2012. Disponível em: <http://www. todospelaeducacao.org.br/educacao-no-brasil/numeros-do-brasil/brasil/ pdf/>. Acesso em: 30 mar. 2013.

Janete Bridon é mestre em Educação na linha de pesquisa Cultura, Tecnologia e Processos de Aprendizagem com os estudos promovidos pelo Grupo de Pesquisa Cultura, Escola e Educação Criadora da UNIVALI. Bolsista integral da Coordenação de Aperfeiçoamento de Pessoal de Nível Superior (CAPES). Graduada em Letras Português com mérito estudantil pela UNIVALI. Graduada em Letras Inglês com mérito estudantil pela UFSC.

E-mail: janeteb99@hotmail.com

Adair de Aguiar Neitzel é doutora em Literatura pela UFSC. Professora do Programa de Mestrado em Educação da UNIVALI. Líder do Grupo de Pesquisa Cultura, Escola e Educação Criadora. Desenvolve pesquisas sobre Leitura, Formação estética e Formação de professores. Desenvolve pesquisa de Pós-doutorado sobre A leitura como prática social em Paris VII - Diderot.

E-mail: neitzel@univali.br 